fournal of Medical Genetics (1973). 10, 101.

\title{
The Skin in Genetically-controlled Metabolic Disorders
}

\author{
P. C. H. NEWBOLD \\ Department of Medicine, Cambridge University Medical School, Hills Road, Cambridge CB2 $2 Q L$
}

Diseased nature oftentimes breaks forth

In strange eruptions.-Henry IV, part 1 , III, i.

The skin is now commonly accepted as a mirror of internal disease, but as with other looking-glasses, the evidence offered may be selected or ignored. The epidermis is an interesting structure, especially rich in tyrosine, phenylalanine, tryptophan, and histidine, when compared with the corium (Rothman, 1965). Tyrosinaemia and histidinaemia do not include cutaneous manifestations, but culture of skin fibroblasts is a helpful diagnostic tool for studying metabolic defects such as citrullinaemia, cystinosis, and maple-syrup urine disease (Scriver, 1969). Most of the conditions now to be described are rare, but if these metabolic diseases were common, there could be no human race as we know it.

\section{Homocystinuria}

This most informative anomaly was discovered during a study of mentally retarded patients in Ireland (Carson and Neill, 1962). The disease is so variable that many asymptomatic cases must be missed, but the incidence is about one in every 40,000 live births. There are two major variants of the disease, one responsive to vitamin B6 and the other not (Gerritsen and Waisman, 1972). In both, lack of the enzyme cystathionine synthase leads to accumulation of homocystine (Mudd et al, 1964), although it is likely that this is partially offset by remethylation of homocysteine to methionine (Carey, Fennelly, and Fitzgerald, 1968). Fig. 1 summarizes the major clinical aspects of homocystinuria. As McKusick (1971) has pointed out, the lens dislocation is acquired and progressive, and therefore may not always be present. If present,

Received 30 November 1972. however, it may lead to difficulty in assessing intelligence, which is within normal range in $50 \%$ of patients. There is suggestive evidence of a relationship between subnormal folate levels and low intelligence (Carey et al, 1968), and studies have shown increased turnover of folate coenzymes and resulting folate depletion in these patients (Carey et al, 1968; Butterworth, Krumdieck, and Baugh, 1971). There is also a high incidence of an organic brain syndrome following intracranial vascular thromboses (Dunn, Perry, and Dolman, 1966),

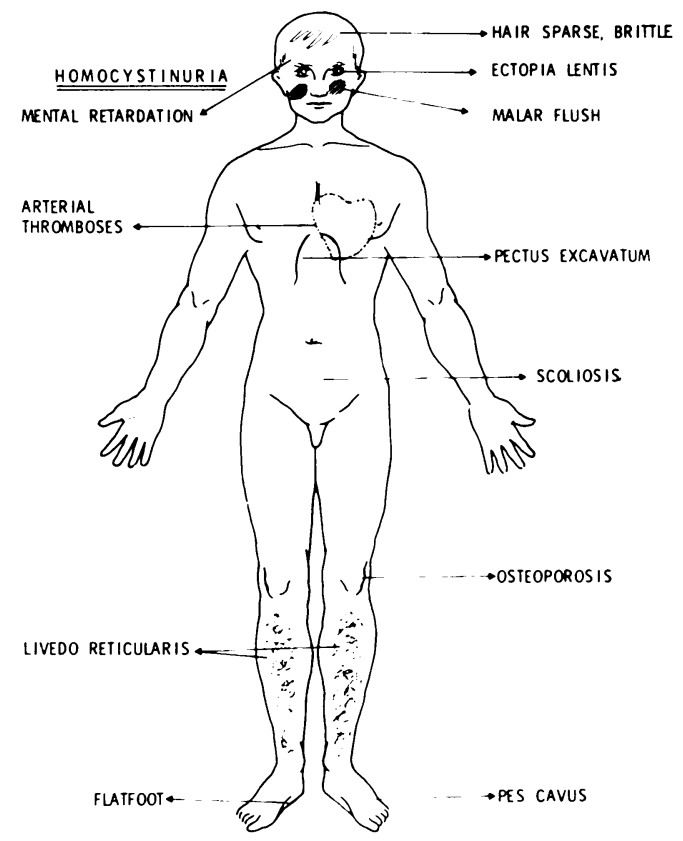

FIG. 1 
which may also be related to the high mortality after anaesthesia (Cusworth and Dent, 1969). The importance of cystathionine, which is one of the major free amino acids in the brain, has not yet been assessed and may be crucial in intelligence (Perry, 1968). It has been shown that the raised blood levels of homocystine increase platelet stickiness (McDonald et al, 1964), and it may be relevant that the abnormal methionine metabolism of homocystinaemia predisposes to atheroma (McCully and Ragsdale, 1970). These chemical abnormalities lead to the vascular lesions which produce arterial and venous thromboses, as well as the malar flush, and the livedo reticularis of trunk and limbs which are significant cutaneous markers. In addition, there is reduction in the colour of skin, hair, and eyes and the hair is thin, sparse, and unusually fragile. Abnormal skin creases and nail-fold capillaries have been noted, together with telangiectases around scars (Price, Vickers, and Brooker, 1968). There are many unsolved problems in this disease. In some patients elevated levels of methionine and homocystine have been found in the aqueous humour (Curtius, Martenet, and Anders, 1968), and in one case normal activity of cystathionine synthase was found in the lens, whereas brain and liver were deficient (Gaull and Gaitonde, 1966). Despite the factors which have been found to increase clotting, many patients have no thromboses, and L-homocystine activates Hageman factor (Gerritsen and Waisman, 1972). Unusual sulphur compounds have been found in the urine, including $S$-adenosyl homocysteine and homolanthionine, and further study may reveal as yet unknown metabolic pathways (Perry, 1968).

\section{Marfan's Syndrome}

In homocystinuria there is generalized osteoporosis, long thin limbs, pectus excavatum, and flat feet producing a picture very like that of Marfan's syndrome. The latter three features are also found in Marfan's syndrome, whereas osteoporosis is rare. In addition, the dislocation of the lens is congenital and upwards (McKusick, 1971), and secondary eye changes are frequent. Weakness of the aortic media produces aneurysms and aortic regurgitation, but there is no thrombotic tendency. Skin involvement is a very minor feature of the syndrome, but striae distensae have been reported especially over the thighs, chest and shoulders (McKusick, 1971). Elastosis perforans serpiginosa of Miescher has also been seen, but this condition has also been found with cutis laxa, the Ehlers-Danlos syndrome, pseudoxanthoma elasticum, osteogenesis imperfecta,
Down's syndrome, and the Rothmund-Thomson syndrome (Meara, 1958; Smith et al, 1962; Korting, 1966), so it is far from diagnostic, except of a dermalepidermal interaction. Other points of distinction from homocystinuria are that the inheritance is autosomal dominant, and that no enzyme deficiency has been found. There seems to be decreased cross-linkage of collagen secondary to a defect such as lack of amine oxidase required to form aldehydes (Grant and Prockop, 1972). Similar changes are seen with lathyrism, and after $\beta$-amino-propionitrile, as well as with penicillamine used in the treatment of scleroderma (Harris and Sjoerdsma, 1966).

\section{Hartnup Disease}

This is another interesting rarity, also fairly recently described (Baron et al, 1956) and of wide fascination. Again variability of expression is seen, and episodes of involvement are intermittent, and decrease in number and severity with age (Jepson, 1972). Cerebellar ataxia may be associated with infections, or be worse when the rash is worse. Headaches are common, and some patients have fainting attacks without ataxia. Mental changes are like those of pellagra, and although some cases are of low inteliigence, one patient is known to be the president of a bank (Jepson, 1972). The rash is most common in summer, and involves exposed areas of face, neck, and limbs. It may be red, dry, and scaly, but sometimes can be exudative. Fig. 2 summarizes the clinical aspects of the disease. The precise nature of the defect is still not decided, but there is reduced activity of the pathway from tryptophan to nicotinamide. So the rash and other features are pellagra-like for the excellent reason that they reflect nicotinamide deficiency. Inheritance is probably autosomal recessive, but this is open to question as some heterozygotes seem to be far from normal. However, the sine qua non of the disease is the specific amino aciduria (Milne, Asatoor, and Loughbridge, 1961). The pattern is important as the total amounts excreted vary so greatly. There is increased output of alanine, serine, threonine, asparagine, glutamine, valine, leucine, isoleucine, phenylalanine, tyrosine, tryptophan, histidine, and citrulline. The transport defect involved has been intensively studied, and one fruit of this work has been knowledge of the transport of amino acids in the gastrointestinal tract and in the kidneys (Milne, 1964). This is a beautiful demonstration of how investigation of a rare disease can add greatly to knowledge of normality. Many of these patients have high urinary excretion of indican, reduced by antibiotics. In the blue-diaper syndrome, the 


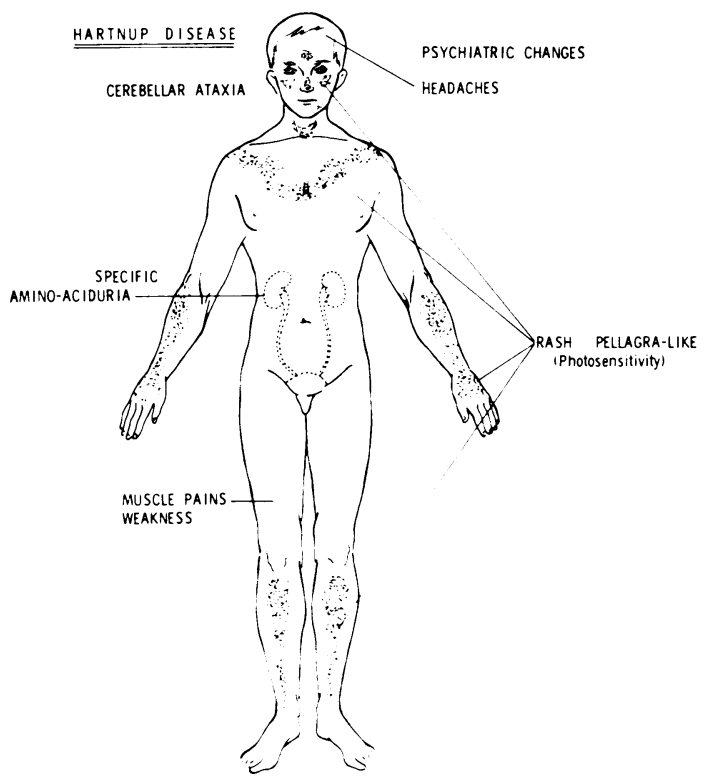

FIG. 2

colour is due to indigotin, an oxidation product of indican. There is a defect in the intestinal transport of tryptophan, features like Hartnup disease, and hypercalcaemia (Drummond et al, 1964). This disease also suggests an unrecognized link between amino-acid metabolism and homoeostasis of calcium and phosphate.

\section{Phenylketonuria}

This is a well-known autosomal recessive disorder, affecting about one per 18,000 live births and it is responsible for about $0.64 \%$ of institutionalized mental patients worldwide. The colour of skin, hair, and eyes is reduced, being especially prominent among dark races such as the Japanese, where patients have brown hair, while their sibs have black hair (Efron and Gallagher, 1971). There is in addition a risk of sunburn, but photosensitivity is not universal (Braun-Falco and Geissler, 1964). Dermatitis is seen in up to $50 \%$ of all patients. Some are true atopic cases (Fleischer and Zeligman, 1960), but in others seborrhoeic dermatitis and autosensitization eruptions may mimic atopic lesions (Efron and Gallagher, 1971). Other patients show an ill-defined and irregular pattern which it is impossible to classify. These skin changes are due to the toxic effects of phenylalanine and its decomposition products in the skin, and respond to dietary restriction of phenylalanine, which must be started very early to reduce brain damage (Murphy, 1958). When diet with normal levels of phenylalanine is resumed, facial eczema may appear within 24 hours. There has also been a report of scleroderma-like skin and muscle indurations in a child of 5 years (Jablonska, Stachow, and Suffczynska, 1967). However, many other skin lesions have been found to have the same incidence in a control group (Braun-Falco and Geissler, 1964).

\section{Hair Abnormalities}

Changes in homocystinuria and phenylketonuria have been mentioned above. Hair fragility is also seen with arginino-succinic aciduria (Rauschkolb, Freeman, and Farrell, 1968), in which the unusual anomaly of monilethrix has also been reported (Mäder and Rose, 1969). Monilethrix may be due to a dominant gene with incomplete penetrance, it is often accompanied by keratosis pilaris, and there may be some overlap with trichorrhexis nodosa. It has also been described, together with pili torti, in the kinky-hair syndrome, with severe mental deficiency (Aguilar et al, 1966a and b; O'Brien et al, 1966). Gross changes in free -SH- groups in the hair keratin cause the kinks, and this seems to be due to a lack of copper (Danks et al, 1972). Copper deficiency also explains the changes in the elastic fibres of arterial walls, the scorbutic bone changes, and the neonatal hypothermia. If treatment with cupric acetate is started rapidly, it may be possible to avert brain damage (Danks et al, 1972). There may be many other disorders to be discovered which involve the hair (Porter and Lobitz, 1970), and a pointer to this has been the recent description of an amine which induces alopecia in mice (Takahara and Takahashi, 1972). Apart from amines and amino acids, metals may be significant, as normal hair contains (in $\mathrm{mg} / \mathrm{kg}$ ) 4.3-8.9 parts of copper, 150 parts of zinc, 5-8 parts of nickel, and 700-4000 parts of calcium (Rothman, 1965). Although it is wellknown that the hair can be a means of elimination, for example of arsenic, many of these other metals remain objects of total mystery.

Proceeding inwards from the epidermis, we encounter the dermis where collagen is of great importance. Indeed, collagen comprises $71.9 \%$ of the dry weight of the skin, whereas elastin is only $0.6 \%$. Collagen contains (in $\mathrm{g} \%$ ) glycine $26 \cdot 2$, proline $15 \cdot 1$, hydroxyproline $14 \cdot 0$, glutamic acid $11 \cdot 3$, alanine $9 \cdot 5$, and arginine $8 \cdot 8$ (Rothman, 1965). Leucine, isoleucine, lysine, phenylalanine, valine, serine, and threonine are also present, but in smaller quantities. Collagen is involved in a number of interesting diseases, in addition to Marfan's syndrome already described. 


\section{Ehlers-Danlos Syndrome}

This heterogeneous entity has been definitively analysed by McKusick (1966). The main features are hyperextensible joints, fragile skin, easy bruising, 'cigarette-paper' scarring, and a generalized fragility of tissues. Premature rupture of membranes leading to premature birth is often seen, and other findings include hiatus hernia, diverticulosis, intestinal perforation, and varicose veins. Structural abnormalities of the media of the arteries can lead to intestinal haemorrhage, rupture of arteries, arteriovenous fistulae and dramatic death (Beighton, 1968; Imahori et al, 1969). Inheritance is probably autosomal dominant, and the basic defect may be a disturbance of the normal 'wicker-work' structure of connective tissue (Jansen, 1955). A variant form has been recently described in which there was a marked decrease in the hydroxylysine content of collagen (Pinnell et al, 1972). This shows autosomal recessive inheritance, and is due to deficient enzymatic hydroxylation of lysine in collagen.

\section{Cutis Laxa}

This is a rare disease in which the skin appears to be too large for the patient. There is a typical mournful facies, and this may be justified by associated pulmonary, gastrointestinal, and ureteric abnormalities (Chadfield and North, 1971). Indeed the condition may be lethal because of involvement of the aorta (Goltz et al, 1965). Some familial cases have been reported with eruptions like urticaria or dermatitis herpetiformis (McCarthy, Warin, and Read, 1965), in addition to occasional concurrence of elastosis perforans (Smith et al, 1962; Korting, 1966). Inheritance has been reported as autosomal recessive or as autosomal dominant with incomplete penetrance, and the latter seems more likely. The tissues show reduction in the size and number of elastic fibres, with granular degeneration and fragmentation, and an excess of acid mucopolysaccharides. The aetiology may be a defect in or a lack of the pancreatic elastase inhibiting substance, leading to excessive elastase activity and subsequent damage to the fibres (Goltz et al, 1965). There may also be a link with low serum copper levels, and copper may be involved in the regulation of the level of circulating elastase (Chadfield and North, 1971).

\section{Pseudoxanthoma Elasticum}

This autosomal recessive disorder has been well studied by McKusick (1966 and 1971). Fig. 3 summarizes the striking clinical features. Angioid streaks, wider than blood vessels and usually grey in colour, may be seen across the fundus, extending

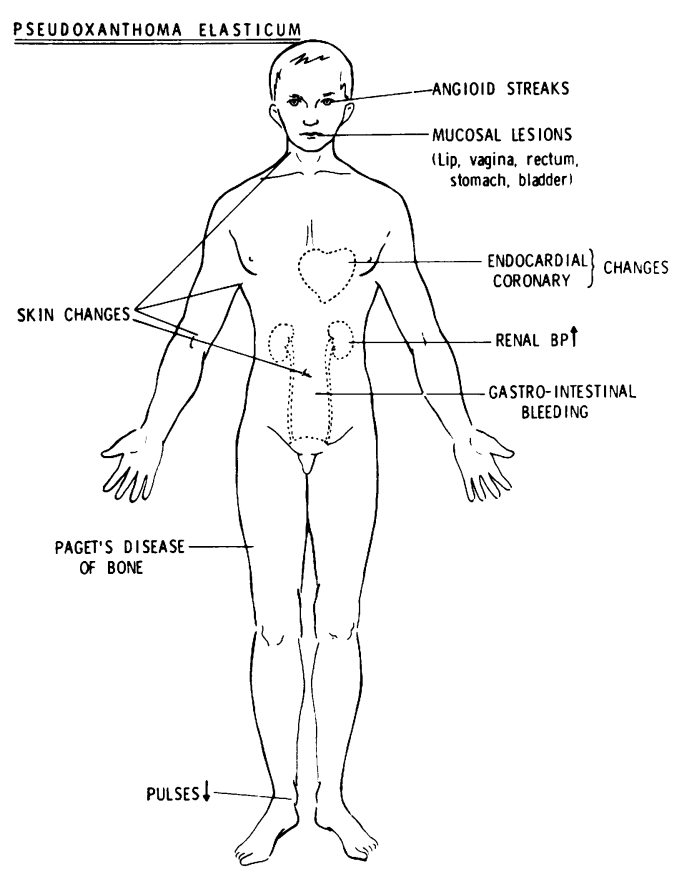

FIG. 3

radially from the optic disc. Trauma, scarring, and haemorrhage may all lead to visual impairment. Angioid streaks are not pathognomonic, as they are also seen, although in a different distribution, with Paget's disease of the bone, familial hyperphosphataemia, and with actinic changes. Yellowish, xanthoma-like, pebbling is seen on the skin like peau d'orange. Sites of predilection are the creases of the face, the neck, the axillary folds, the antecubital fossae, around the umbilicus, and the inguinal areas. The elastic fibres are fragmented, and show calcification in the deeper layers of the corium, and reactive perforating elastosis is sometimes seen (Smith et al, 1962). This comprises clusters of papules in rings or whorls, especially on the hairless regions of the neck, and less often on the cheeks or the extremities. The papules may be conical or flat-topped, 2-3 mm in diameter, and with a central keratotic plug. Mucosal lesions involve the lower lip, rectum, vagina, stomach, and bladder. Gastrointestinal haemorrhage is a significant feature and raised yellow submucous lesions have been observed in the stomach (Cocco et al, 1969). Renal hypertension follows involvement of the renal arteries and calcification of other arteries can lead to absent or reduced pulses in the extremities and a risk of coronary thrombosis. Paget's disease of the 
bones can also coexist. The clinical picture is so bizarre that hysteria and malingering can be suspected, and the first two patients I saw had both been diagnosed as Munchhausen's syndrome. It is presumed that there is an enzyme deficiency which leads to the accumulation of an abnormal substance which damages connective tissue, but the basic defect has not yet been defined.

Another vital function of the skin is concerned with protection from ultra-violet light, and here the pigmentary system is of crucial importance.

\section{Albinism}

Melanoblasts migrate from the neural crest to the nervous system, the uveal tract, skin, and mucous membranes during embryonic life. They function as melanocytes, in which melanin is synthesized within melanosomes by the oxidation of tyrosine, a reaction which depends on tyrosinase, a coppercontaining enzyme. If the entire melanocyte system is involved in the abnormality, then the recessive oculocutaneous albinism results. There are two forms, tyrosinase-negative and tyrosinasepositive (Fitzpatrick et al, 1971). The term albinism is also used loosely to include many other hypopigmented conditions such as piebaldness. The details are probably immensely complex, as animal studies indicate that over 70 genes are involved, and in mice at least, the dermal component is probably crucial (Mayer and Fishbane, 1972). The major interest to clinicians is the severe photosensitivity of albinos and their associated risk of basal and squamous cell epitheliomata and malignant melanomata (Bhende, 1952; Shapiro et al, 1953; Young, 1957; Leonardi and Grasso, 1958).

\section{Alcaptonuria}

Inbreeding has produced many reports of apparent dominance of this disorder, whereas its inheritance is recessive. Careful studies have shown that the defect is of the enzyme homogentisic acid oxidase (La Du, 1972). Homogentisic acid produced during the metabolism of phenylalanine and tyrosine accumulates is spilled into the urine, which then darkens on standing. Alkali increases the effect, so that soap on napkins and clothing darkens the colour. Vitamin $\mathrm{C}$ protects against this effect, which explains why some patients never show dark urine (Minno and Rogers, 1957). Fig. 4 shows the main clinical features. Widespread grey to bluish-black pigmentation, which looked like ochre under the microscope, was described by Virchow in 1866. The association between ochronosis and alcaptonuria was made by Albrecht in 1902. Eye involvement is usually the first sign of

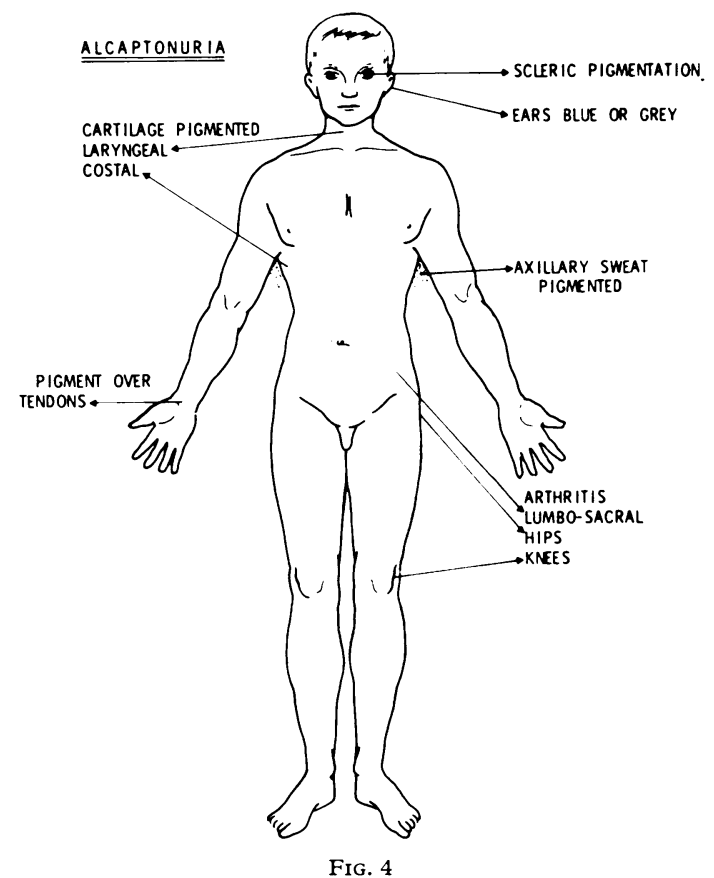

the disease, appearing in the third decade, and pigment is seen around the insertion of the rectus muscles. There may also be pigmentation of the cornea and conjunctiva. The ear changes are seen later, and some patients also show dusky pigmentation of the skin of the hands, usually over underlying tendons. Patients who show dark urine may also show pigment in their sweat, with consequent damage to clothing. Long-standing cases also show an arthritis, which is clinically like rheumatoid arthritis, but radiologically like osteoarthritis. Changes include degeneration of the lumbar invertebral discs with narrowing of the spaces, and dense calcification of the remaining disc material. There is also a variable degree of fusion of vertebral bodies. The changes are so typical that the disease can be initially picked up by a radiologist (Pomeranz, Friedman, and Tunick, 1941). How far the pigmentation is due to the enzyme defect is debatable, as acquired cases have been seen after atabrine treatment (Ludwig, Toole, and Wood, 1963), and also after prolonged use of carbolic acid dressings for ulcers (Beddard, 1910; Brogren, 1952). However, in mammalian skin and cartilage an enzyme has been found, homogentisic acid polyphenol oxidase, which catalyses the formation of ochronosislike pigment (Zannoni, Lomtevas, and Goldfinger, 1969). 
It is possible that other metabolic disorders involve the pigmentary system, and some will include acanthosis nigricans (Reed et al, 1968). However, as these are mostly at the stage of clinical description only, without knowledge of their chemical background, they will not be included in this review.

Apart from collagen, the major component of the dermis is fat. This tissue produces many lesions of diagnostic import, and these will be considered separately.

\section{Hyperlipoproteinaemias}

Xanthelasma was included, without comment, in Rayer's atlas of 1835, and after Addison and Gull, much interest was aroused in xanthomata. The Guy's dermatologists added to this, and names multiplied, eventually to be simplified by lipoprotein analyses, ultracentrifugation, and paper electrophoresis (Fredrickson and Levy, 1972).

Type 1 has decreased plasma post-heparin lipoprotein lipase activity, and the defect is probably in the tissue activity of this enzyme. The syndrome is the homozygous expression of an autosomal allele, but more than one mutation may produce the same phenotype.

Type 2 is familial hyperbeta-lipoproteinaemia, but the biochemical defect has not yet been defined. Heterozygous and homozygous forms are seen, and premature vascular disease and polyarthritis are important features.

Type 3, broad beta disease, is uncommon and of uncertain chemical background and inheritance. It is associated with decreased glucose tolerance, premature vascular disease and hyperuricaemia.

Type 4 is also linked with decreased glucose tolerance, but diabetes is not often seen as hyperinsulinaemia is frequent. These patients tend to be lean, yet have vascular disease, and a risk of infarcts.

Type 5 features abdominal pain and hepatosplenomegaly like type 1, and diabetes and hyperuricaemia, but no apparent excess of vascular disease.

There is danger from complications, and a long latency before these appear, so it is important to recognize these conditions as treatments are available (Lees and Wilson, 1971). The xanthomata, which present on the skin, are therefore amongst the most important of cutaneous markers of metabolic disease (Parker and Short, 1970). Table I summarizes this information both from the types of disease and the types of xanthoma.
TABLE I

\section{XANTHOMATA AND HYPERLIPOPROTEINAEMIAS}

\begin{tabular}{|c|c|}
\hline Type 1 & Eruptive, any site \\
\hline Type 2 & $\begin{array}{l}\text { Xanthelasma, others according to severity and duration, } \\
\text { in } 80 \% \\
\text { Tendinous in } 50 \% \\
\text { Subperiosteal lesions occasionally }\end{array}$ \\
\hline Type 3 & $\begin{array}{l}\text { Planar lesions on palms } \\
\text { Tendinous in } 20 \% \text {; tubero-eruptive and subperiosteal } \\
\text { lesions common }\end{array}$ \\
\hline Type 4 & Eruptive lesions in $15 \%$ \\
\hline Type 5 & Eruptive, and tubero-eruptive in $45 \%$ \\
\hline Tendinous & Mainly in type 2 , in 3 to lesser extent \\
\hline Tuberous & Mainly in type 3 , less in 2 , rare in 1,4 , and 5 \\
\hline Planar & Mainly in type 2 , palmar only in 3 \\
\hline Eruptive & Mainly in types 1,4 , and 5 , less often in 3 \\
\hline
\end{tabular}

Eruptive xanthomata appear when the plasma triglycerides exceed $1500 \mathrm{mg} / 100 \mathrm{ml}$, even for a short time. Each lesion consists of a yellowish nodule upon a slightly erythematous base, but they may coalesce. When treatment is started and the chemistry is corrected, the lesions disappear in a few weeks. Planar xanthomata are seen in the superficial skin over the extremities, especially the buttocks and hands. Tendinous lesions favour the tendo Achillis and the extensor tendons of the hands, while tuberous lesions are most common at the elbows. Subperiosteal xanthomata are most frequent below the knee and over the olecranon process. Of all the lesions, the one with the smallest diagnostic significance is xanthelasma. It must also be remembered that secondary hyperlipoproteinaemia can-amongst other associations-occur with pancreatitis, uraemia and the nephrotic syndrome, lymphoma and myeloma, glycogen storage disease, and myxoedema.

\section{Tangier Disease}

This familial lipoprotein deficiency is most familiar for the enlarged orange-yellow tonsils with coloured striations. There is deposition of cholesterol esters both in papules and in skin which may look normal (Waldorf, Levy, and Fredrickson, 1967). Inheritance is recessive, and there is severe deficiency of normal $\alpha$-lipoproteins in plasma, with circulation of a small amount of an aberrant high density lipoprotein. In addition, the cholesterol esters are deposited in liver, spleen, lymph nodes, cornea, intestine, and possibly in blood vessels (Fredrickson, Gotto, and Levy, 1972). There may also be unusual neurological changes which are asymmetrical and fluctuating (Kocen et al, 1967). 
It is possible that this polyneuropathy is on the basis of associated arterial disease, but its natural history has not yet been established.

\section{Lipoid Proteinosis}

This rare recessive disorder is also known as hyalinosis cutis et mucosae, and most of the reported cases are from South Africa (Scott and Findlay, 1960). The age of diagnosis may be as late as 67 years, but is most common in childhood, as the infant is unable to cry, and later can only whisper with a hoarse voice. This hoarseness and crying difficulty are also seen in Farber's disease, an even rarer granulomatous disorder, with a defect in metabolism of acid mucopolysaccharides (Abul-Haj et al, 1962). Crops of sores and ulcers involve the mouth and infiltration of the mucous membranes of tongue, larynx, and vocal cords follows. The tongue and lips are thickened, with irregular scars and yellowish infiltrated plaques (Grosfeld et al, 1965). Other features include recurrent infections, bullae and pustules which predispose to scars, and papules which precede the plaques. Alopecia, loss of eyelashes, hyploplasia of teeth, bossing of the skull, and eccentric pupils may also occur, while there is an increased incidence of diabetes (Burnett, 1971). The skin lesions mainly involve the face, neck, shoulders, axillae, lower back, and the dorsal aspects of hands and fingers. Individual lesions tend to be arranged linearly along the skin creases. Light sensitivity is a feature of some patients (Klevansky, 1960; Calnan and Shuster, 1962), and tissues show a hyaline material similar to that which occurs in solar elastosis, pophyria cutanea tarda, and erythropoietic protoporphyria. These porphyrias also show a similar perivascular involvement, and great proliferation of the basement membrane, and porphyrinuria has been associated with lipoid proteinosis (Burnett, 1971). The deposit occurs around arterioles, capillaries, sweat glands, and arrectores pilorum in skin, but it has also been found in many other tissues of the body (Caplan, 1967). Chemically, the nature of the material is still uncertain (Fleischmajer et al, 1969). Normal lipids only have been reported (Heyl and DeKock, 1964), as have galactolipids (Wood, Urbach, and Beerman, 1956), and mucopolysaccharides (Moynahan, 1966). It is likely that the changes are variable, and the deposits may only be incidental, as it has not yet been established if they are primary or secondary. Treatment is mainly speedy attention to infections to reduce scarring, and laryngotomy may be necessary for vocal cord thickening, but the prognosis seems to be good.
Fabry's Disease

This X-linked recessive disorder is due to lack of $\alpha$-galactosyl hydrolase, which is necessary to break down trihexosyl ceramide. Hence glycosphingolipid accumulates and deposits cause the clinical syndrome, which is shown in Fig. 5. The pains may be a presenting feature, are excruciating enough sometimes to drive sufferers to suicide, and involve the fingers and toes. Associated paraesthesiae may spread into hands and feet, and there is a good response to treatment with diphenylhydantoin (Lockman, Krivit, and Desnick, 1971). I have used this in two patients with success, when morphine and analogues had been exhibited without relief. Bouts of fever may accompany the pain, and cases have been diagnosed as rheumatic fever (Sweeley et al, 1972). The skin lesions bear the ponderous title of angiokeratoma corpis diffusum universale, but true Fabry's disease can occur without any skin component (Clarke et al, 1971). The lesions are actually telangiectases, small and dark-red, usually flat and superficial, and not fading on pressure. Major sites are the hips, thighs, back, buttocks, and genitals, and the mucosae of conjunctiva and mouth are also frequently involved (Frost, Spaeth, and Tanaka, 1966; van Mullem and Ruiter, 1966; Imperial and Helwig, 1967; Sagebiel and Parker, 1968).

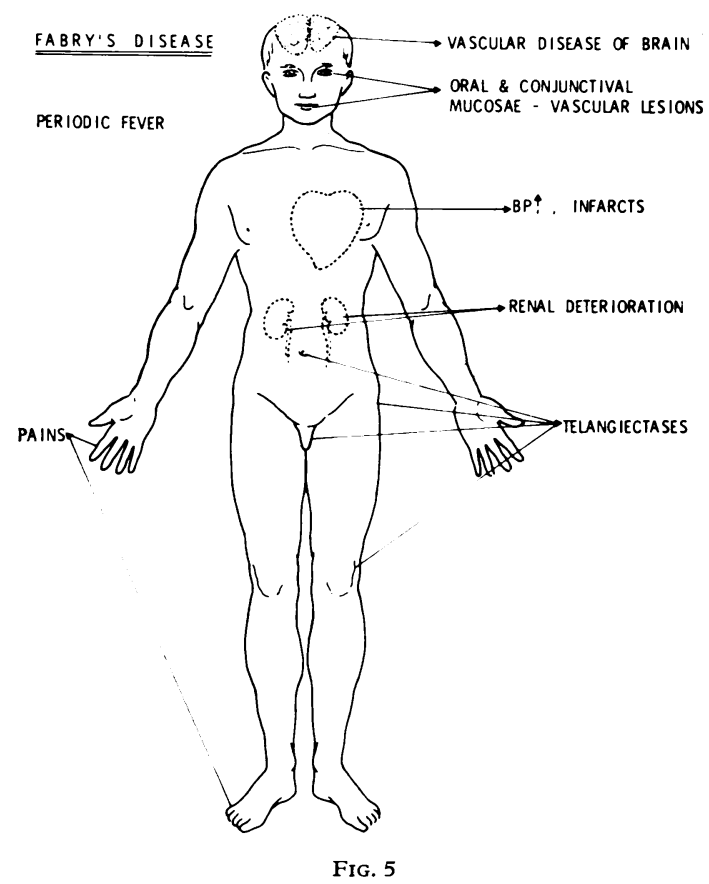


Deposits of the ceramides also occur in the eye, leading to oedema of the eyelids, and corneal opacities-which can also occur in female heterozygotes. Vascular deposits lead to damage to brain, kidneys, and heart, while renal hypertension compounds the cardiac injuries. The automatic nervous system is also involved leading to hypohidrosis and diarrhoea (Sweeley et al, 1972). Many other findings can be seen, but the commonest presentations are pain, skin lesions, and renal failure. Treatment is unsatisfactory, although enzyme infusions have been used with success, and enzyme replacement may be feasible in the future (Sweeley et al, 1972).

\section{Refsum's Syndrome}

Refsum described his syndrome in 1946 under the title of heredopathia atactica polyneuritiformis and it exhibits autosomal recessive inheritance. The basis of the disease is accumulation of the unusual 20-carbon branched-chain phytanic acid (Steinberg, 1972). Constant clinical features are retinitis pigmentosa, peripheral neuropathy, cerebellar ataxia, and raised CSF protein with normal cells. Nerve deafness, anosmia, abnormal pupils, cardiogram changes, and variable ichthyosis may also be seen (Fryer et al, 1971). The phytanic acid which accumulates comes mainly from dairy products, with traces from tomatoes and other foods. The estimated daily intake is $56 \mathrm{mg}$ on a hospital diet in America and $89 \mathrm{mg}$ in New Zealand (Steinberg et al, 1970). With dietary restrictions, also excluding chlorophyll which is a source of phytol, good results are seen.

These latter diseases have all shown the skin as a storage organ, but in the porphyrias the major cutaneous signs are due to photosensitivity.

\section{Porphyrias}

Acute intermittent porphyria features acute abdominal crises, and neuropsychiatry, with much chemical background to explain these symptoms (Meyer et al, 1972). However, as skin involvement does not occur, we will briefly consider variegate porphyria instead.

This is another hepatic porphyria, with autosomal dominant inheritance, and acute episodes triggered by drugs or insults to the liver. In addition, there is chronic sensitivity to light and to trauma, although patients show great variation in the nature and extent of their lesions. Bullae and scars are the major skin signs, and occur most commonly on the backs of the hands. Hereditary coproporphyria is also a hepatic type, again with dominant inheritance, and latent cases are common. Light sensitivity and abdominal symptoms are mild, although acute attacks can occur. There is increased enzymatic synthesis of $\delta$-aminolaevulinic acid (ALA) in the liver, possibly on the basis of disturbance of the normal role of haem in the feedback regulation of ALA-synthetase (Kaufman and Marver, 1970).

Porphyria cutanea tarda is usually acquired, often due to alcohol, which may be uncovering a latent genetic defect (Moore et al, 1972). Fragile skin, photosensitivity with increased pigmentation, and hypertrichosis of exposed areas are the clinical features and the action spectrum has been defined (Magnus, Porter, and Rimington, 1959). Acute attacks do not occur in this variety. Many thousands of cases occurred in Turkey with the epidemic of hexachlorobenzene poisoning, and these cases featured vesicles, scars, alopecia, ectropion, and corneal opacities (Schmid, 1960; Cam and Nigogosyan, 1963). It is of interest that studies in rats have indicated that protein deficiency contributes to the clinical picture (Magnus, Roe, and Bhutani, 1969). Haemosiderosis is invariable, and venesection, introduced by von Ippen in 1961, helps both chemically and clinically.

Erythropoietic porphyria, or Günther's disease, is one of the best studied rarities in medical literature. It is an autosomal recessive, and fewer than 100 cases are known. Light sensitivity in childhood produces hydroa aestivale, but later, scarsworse with infection-lead to ulceration and deformity. The loss of hair, nose, ears, eyelids, lips, and fingers produces great mutilation which may be one of the historical threads in the origin of the werewolf legend (Illis, 1964). Other features are splenomegaly and haemolytic anaemia, for which splenectomy has been tried (Gray and Neuberger, 1952), sometimes with benefit. Red urine and hypertrichosis add dramatic highlights to a condition nobody would wish for themselves. Erythropoietic protoporphyria is now more usually called simply protoporphyria. It was described in 1961, as light-induced urticaria (Magnus et al, 1961). However, as the disease is transmitted via an autosomal dominant with variable penetrance there are many latent cases. Consequently, photosensitivity alone cannot be used as a genetic marker (Reed et al, 1970). It is a mild disorder, and a softening finale after the horrors of Günther's disease.

\section{Miscellaneous}

Copper has already been mentioned as an interesting aspect of the kinky-hair syndrome. The autosomal recessive Wilson's disease exhibits cirrhosis of the liver, degeneration of the basal ganglia, and 
complex abnormalities of renal function. KayserFleischer rings are greenish in colour, most marked at the superior and inferior aspects of the cornea, are seldom complete, and usually accompany neurological damage. They may fade with penicillamine treatment, which has been standard since 1956 (Walshe, 1956). The pathogenesis of the disease is still not fully clear, but it is accompanied by slow accumulation of copper, probably due to decreased synthesis of normal caeruloplasmin.

Copper may also be of importance in vitiligo, as the serum of patients has been found to contain raised levels of both copper and caeruloplasmin. These return to normal, and melanogenesis is resumed, after heliotherapy (Genov, Bozhkov, and Zlatkov, 1972). It has therefore been postulated that vitiligo is due to genetically determined structural changes in the messenger RNA, which synthesizes apoenzyme with a decreased ability to bind copper.

Iron metabolism is also of cutaneous interest. Haemochromatosis may be familial, but the disease is too rare to permit the inheritance to be defined, although relatives of patients do handle iron abnormally. It appears that in normality the skin conserves iron, as it does DNA, by reabsorption from the basal layers (Cavill et al, 1969). Iron deposits lead to epidermal thinning, via local damage, as well as to the well-known cirrhosis, diabetes, and heart disease (Cawley et al, 1969). As vitiligo can occur in the presence of haemochromatosis, the skin pigmentation is due solely to melanin (Perdrup and Poulsen, 1964). The pigment is probably produced in response to damage to melanocytes by haemosiderin, but it can fade after repeated phlebotomies (Cawley et al, 1969).

By contrast, the iron-deficiency syndrome known by various eponyms, certainly includes koilonychia, angular cheilitis and glossitis, and possibly a risk of malignancy, but it does not seem to have a familial tendency (Schetman, 1972). Of great interest is a possible link between iron deficiency and familial chronic muco-cutaneous candidiasis which is an autosomal recessive disorder (Higgs and Wells, 1972; Wells et al, 1972).

Skin diseases pose special problems for the molecular biologist, and new genetic mechanisms and increased understanding both of 'normality' and of polymorphisms will be necessary before most of the common dermatoses can be included in a future review of this field (Cotton and Mier, 1972; Hopkinson, 1972). Certain candidates for study present themselves at present. Lichen planus may be due to an abnormality in glucose-6-phosphate dehydrogenase in the skin, as recent studies have revealed kinetic differences from normality (Cotton, van den Hurk, and van der Staak, 1972). Epidermolysis bullosa dystrophica has blisters which might be explained by excess production of skin collagenase (Eisen, 1969). Certainly, advances in the understanding of the chemistry of collagen and collagenase are likely to shed light into many dark corners (Grant and Prockop, 1972; Lazarus, 1972). Similar illumination may come from knowledge of histidine and urocanic acid chemistry (Baden and Pathak, 1967), as well as increased understanding of amyloid and its precursors. The next decade may well see a greater contribution by dermatologists to general medical knowledge, whereas the reverse has prevailed until recently.

I am grateful to Mrs M. Sheldon, Medical Artist at Addenbrooke's Hospital, for her skilled assistance with the Figures.

I should also like to acknowledge more than a decade of help, encouragement and hospitality from Professor Robert Mahler of the Department of Medicine, Cardiff. I am currently in receipt of the Elmore Studentship of the University of Cambridge, and am supported financially by the Medical Research Council.

\section{REFERENCES}

Abul-Haj, S. K., Martz, D. G., Douglas, W. F., and Geppert, L. J. (1962). Farber's disease: report of a case with observations on its histogenesis and notes on the nature of the stored material. fournal of Pediatrics, 61, 221-232.

Aguilar, M. J., Chadwick, D. L., Okuyama, K., and Kamoshita, S. (1966a). Kinky hair disease. Clinical and pathological features. fournal of Neuropathology and Experimental Neurology, 25, 507522.

Aguilar, M. J., Chadwick, D. L., Okuyama, K., and Kamoshita, S. (1966b). Kinky hair disease. Biochemical studies. Fournal of Neuropathology and Experimental Neurology, 25, 523-530.

Albrecht, H. (1902). Ueber Ochronose. Zeitschrift für Heilkunde, section 3, 23, 366-378.

Baden, H P. and Pathak, M. A. (1967). The metabolism and function of urocanic acid in skin. Fournal of Investigative Dermato$\log y, 48,11-17$.

Baron, D. N., Dent, C. E., Harris, H., Hart, E. W., and Jepson, J. B. (1956). Hereditary pellagra-like skin rash with temporary cerebellar ataxia, constant renal aminoaciduria, and other bizarre biochemical features. Lancet, 2, 421-428.

Beddard, A. P. (1910). Ochronosis associated with carboluria. Quarterly fournal of Medicine, 3, 329-336.

Beighton, P. (1968). Lethal complications of the Ehlers-Danlos syndrome. British Medical fournal, 3, 656-659.

Bhende, Y. M. (1952). Malignant amelanotic melanoma of the skin in an albino. Indian fournal of Medical Science, 6, 755-759.

Braun-Falco, O. and Geissler, H. (1964). Hauterscheinungen bei Phenylketonurie. Medizinische Welt, 2, 1941-1947.

Brogren, N. (1952). Case of exogenetic ochronosis from carbolic acid compresses. Acta Dermatovenereologica, 32, 258-260.

Burnett, J. W. (1971). Lipoid proteinosis. In Dermatology in General Medicine, ed. by T. B. Fitzpatrick, K. A. Arnolt, W. H. Clark, A. Z. Eisen, E. J. van Scott, and J. H Vaughan. McGrawHill, New York.

Butterworth, C. E., Krumdieck, C. L., and Baugh, C. M. (1971). Studies on the absorption and metabolism of folic acid. 2. Homocystinuria. Alabama fournal of Medical Sciences, 8, 3043.

Calnan, C. D. and Shuster, S. (1962). Lipoid proteinosis. Proceedings of the Royal Society of Medicine, 55, 957-958.

Cam, C. and Nigogosyan, G. (1963). Acquired toxic porphyria cutanea tarda due to hexachlotobenzene. Fournal of American Medical Association, 183, 88-91. 
Caplan, R. M. (1967). Visceral involvement in lipoid proteinosis. Archives of Dermatology, 95, 149-155.

Carey, M. C., Fennelly, J. J., and Fitzgerald, O. (1968). Homocystinuria. 2. Subnormal folate levels, increased folate clearance and effects of folic acid therapy. American fournal of Medicine, 45, 26-31.

Carson, N. A. J. and Neill, D. W. (1962). Metabolic abnormalities detected in a survey of mentally backward individuals in Northern Ireland. Archives of Disease in Childhood, 37, 505-513.

Cavill, I., Jacobs, A., Beamish, M., and Owen, G. (1969). Iron turnover in the skin. Nature, 222, 167-168.

Cawley, E. P., Hsu, Y. T., Wood, B. T., and Weary, P. E. (1969). Hemochromatosis and the skin. Archives of Dermatology, 100, $1-6$.

Chadfield, H. W. and North, J. F. (1971). Cutis laxa. A report of three cases. Transactions of the St. Fohn's Hospital Dermatological Society, 57, 181-189.

Clarke, J. T. R., Knaack, J., Crawhall, J. C., and Wolfe, L. S. (1971). Ceramide trihexogidosis (Fabry's disease) without skin lesions. New England fournal of Medicine, 284, 233-235.

Cocco, A. E., Grayer, D. I., Walker, B. A., and Martyn, L. J. (1969). Stomach in pseudoxanthoma elasticum. Fournal of the American Medical Association, 210, 2381-2382.

Cotton, D. W. K., Hurk, J. J. M. A. van den, and Staak, W. B. J. M. van der (1972). Lichen planus; an inborn error of metabolism. British fournal of Dermatology, 87, 341-346.

Cotton, D. W. K. and Mier, P. D. (1972). The molecular basis of metabolic skin disorders. Transactions of the St. Fohn's Hospital Dermatological Society, 58, 108-110.

Curtius, H.-C., Martenet, A. C., and Anders, P. W. (1968). Bestimmung von freien Aminosäuren in Augenkammerwasser des Menschen bei Homocystinurie-Patienten und Kontrollfällen. Clinica Chimica Acta, 19, 469-476.

Cusworth, D. C. and Dent, C. E. (1969). Homocystinuria. British Medical Bulletin, 25, 42-47.

Danks, D. M., Stevens, B. J., Campbell, P. E., Gillespie, J. M., Walker-Smith, J., Blomfield, J., and Turner, B. (1972). Menkes' kinky-hair syndrome. Lancet, 1, 1100-1103.

Drummond, K. N., Michael, A. F., Ulstrom, R. A., and Good, R. A. (1964). The blue diaper syndrome: familial hypercalcemia with nephrocalcinosis and indicanuria. American fournal of Medicine, 37, 928-948.

Dunn, H. G., Perry, T. L., and Dolman, C. L. (1966). Homocystinuria: a recently discovered cause of mental defect and cerebrovascular thrombosis. Neurology, 16, 407-420.

Efron, M. L. and Gallagher, W. F. (1971). Phenylketonuria. In Dermatology in General Medicine, ed. by Fitzpatrick et al. McGrawHill, New York.

Eisen, A. Z. (1969). Human skin collagenase: relationship to the pathogenesis of epidermolysis bullosa dystrophica. Fournal of Investigative Dermatology, 52, 449-453.

Fitzpatrick, T. B., Quevedo, W. C. Jr., Szabo, G., and Seiii, M. (1971). Biology of the melanin pigmentary system. In Dermatology in General Medicine, ed. by Fitzpatrick et al. McGraw-Hill, New York.

Fleischer, T. L. and Zeligman, I. (1960). Cutaneous findings in phenylketonuria. Archives of Dermatology, 81, 898-903.

Fleischmajer, R., Nedwich, A., and Ramos e Silva, J. (1969). Hyalinosis cutis et mucosae. A histochemical staining and analytical biochemical study. Fournal of Investigative Dermatology, 52, 495503.

Fredrickson, D. S., Gotto, A. M., and Levy, R. I. (1972). Familial lipoprotein. In The Metabolic Basis of Inherited Disease, 3rd edition, ed. by J. B. Stanbury, J. B. Wyngaarden, and D. S. Fredrickson, pp. 493-530. McGraw-Hill, New York.

Fredrickson, D. S. and Levy, R. I. (1972). Familial hyperlipoproteinaemia. In The Metabolic Basis of Inherited Disease, 3rd edition, ed. by Stanbury et al, pp. 545-614. McGraw-Hill, New York.

Frost, P., Spaeth, G. L., and Tanaka, Y. (1966). Fabry's disease: glycolipid lipidosis. Skin manifestations. Archives of Internal Medicine, 117, 440-446.

Fryer, D. G., Winckleman, A. C., Ways, P. O., and Swanson, A. G. (1971). Refsum's disease. A clinical and pathological report. Neurology, 21, 162-167.

Gaull, G. and Gaitonde, M. K. (1966). Homocystinuria: an observation on the inheritance of cystathionine synthase deficiency. fournal of Medical Genetics, 3, 194-197.
Genov, D., Bozhkov, B., and Zlatkov, N. B. (1972). Copper pathochemistry in vitiligo. Clinica Chimica Acta, 37, 207-211.

Gerritsen, T. and Waisman, H. A. (1972). Homocystinuria. In The Metabolic Basis of Inherited Disease, 3rd edition, ed. by Stanbury et al, pp. 404-412. McGraw-Hill, New York.

Goltz, R. W., Hult, A. M., Goldfarb, M., and Gorlin, R. J. (1965). Cutis laxa. A manifestation of generalized elastolysis. Archives of Dermatology, 92, 373-387.

Grant, M. E. and Prockop, D. J. (1972). The biosynthesis of collagen, 3. New England fournal of Medicine, 286, 291-300.

Gray, C. H. and Neuberger, A. (1952). Effect of splenectomy in a case of congenital porphyria. Lancet, 1, 851-854.

Grosfeld, J. C. M., Spaas, J., Staak, W. J. B. M. van der, and Stadhouders, A. M. (1965). Hyalinosis cutis et mucosae. Dermatologica, 130, 239-266.

Harris, E. D. and Sjoerdsma, A. (1966). Effect of penicillamine on human collagen and its possible application to treatment of scleroderma. Lancet, 2, 996-999.

Heyl, T. and DeKock, D. H. (1964). A chromatographic study of skin lipids in lipoid proteinosis. Fournal of Investigative Dermatology, 42, 333-336.

Higgs, J. M. and Wells, R. S. (1972). Chronic muco-cutaneous candidiasis: associated abnormalities of iron metabolism. British fournal of Dermatology, 86, Supplement No. 8, 88-102.

Hopkinson, D. A. (1972). The genetics of metabolic disorders. Postgraduate Medical fournal, 48, 207-211.

Illis, L. (1964). On porphyria and the aetiology of werwolves. Proceedings of the Royal Society of Medicine, 57, 23-26.

Imahori, S., Bannerman, R. M., Graf, C. J., and Brennan, J. C. (1969). Ehlers-Danlos syndrome with multiple arterial lesions. American fournal of Medicine, 47, 967-977.

Imperial, R. and Helwig, E. B. (1967). Angiokeratoma: a clinicopathological study. Archives of Dermatology, 95, 166-175.

Ippen, H. von (1961). Allgemeinsymptome der späten Hautporphyrie (Porphyria cutanea tarda) als Hinweise für deren Behandlung. Deutsche Medizinische Wochenschrift, 86, 127-133.

Jablonska, S., Stachow, A., and Suffczynska, M. (1967). Skin and muscle indurations in phenylketonuria. Archives of Dermatology, 95, 443-450.

Jansen, L. H. (1955). The structure of the connective tissue, an explanation of the symptoms of the Ehlers-Danlos syndrome. Dermatologica, 110, 108-120.

Jepson, J. B. (1972). Hartnup disease. In The Metabolic Basis of Inherited Disease, 3rd edition, ed. by Stanbury et al, pp. 14861503. McGraw-Hill, New York.

Kaufman, L. and Marver, H. S. (1970). Biochemical defects in two types of human hepatic porphyria. New England fournal of Medicine, 283, 954-958.

Klevansky, H. (1960). Lipoid proteinosis. British fournal of Dermatology, 72, 195-196.

Kocen R. S., Lloyd, J. K., Lascelles, P. T., Fosbrooke, A. S., and Williams, D. (1967). Familial $\alpha$-lipoprotein deficiency (Tangier disease) with neurological abnormalities. Lancet, 1, 1341-1345.

Korting, G. W. (1966). Elastosis perforans serpiginosa als ektodermales Randsymptom bei Cutis laxa. Archiv für Klinische und Experimentelle Dermatologie, 224, 437-446.

La Du, B. N. (1972). Alcaptomuria. In The Metabolic Basis of Inherited Disease, 3rd edition, ed. by Stanbury et al, pp. 308-325. McGraw-Hill, New York.

Lazarus, G. S. (1972). Collagen, collagenase and clinicians. British fournal of Dermatology, 86, 193-199.

Lees, R. S. and Wilson, D. E. (1971). The treatment of hyperlipidemia. New England fournal of Medicine, 284, 186-195.

Leonardi, R. and Grasso, S. (1958). Melanoblastoma in albino. Minerva Dermatologica, 33, 24-26.

Lockman, L. A., Krivit, W., and Desnick, R. J. (1971). Relief of the painful crises of Fabry's disease by diphenylhydantoin. Neuro$\log y, 21,423$.

Ludwig, G. D., Toole, J. F., and Wood, J. C. (1963). Ochronosis from quinacrine (atabrine). Annals of Internal Medicine, 59, 378-384.

McCarthy, C. F., Warin, R. P., and Read, A. E. A. (1965). Loose skin (cutis laxa) associated with systemic abnormalities. Archives of Internal Medicine, 115, 62-67.

McCully, K. S. and Ragsdale, B. D. (1970). Production of ateriosclerosis by homocysteinemia. American fournal of Pathology, 61, 1-8. 
McDonald, L., Bray, C., Field, C., Love, F., and Davies, B. (1964). Homocystinuria, thrombosis, and the blood-platelets. Lancet, 1 , 745-746.

McKusick, V. A. (1966). Heritable Disorders of Connective Tissue, 3rd edition. C. V. Mosby, St Louis.

McKusick, V. A. (1971). Pseudoxanthoma elasticum. In Dermatology in General Medicine, ed. by T. B. Fitzpatrick et al. McGrawHill, New York.

Mäder, A. K. and Rose, H. J. (1969). Monilethrix und Argininbernsteinsäure-Ausscheidung. Dermatologische Monatsschrift, 155 409-416.

Magnus, I. A., Jarrett, A., Prankerd, T. A. J., and Rimington, C. (1961). Erythropoietic protoporphyria. A new porphyria syndrome with solar urticaria due to protoporphyrinaemia. Lancet, 2, 448-451.

Magnus, I. A., Porter, A. D., and Rimington, C. (1959). The action spectrum for skin lesions in porphyria cutanea tarda. Lancet, 1, 912-914.

Magnus, I. A., Roe, D. A., and Bhutani, L. K. (1969). Factors affecting the induction of porphyria in the laboratory rat. Biochemical and photobiological studies using diethyl 1,4-dihydro2,4,6-trimethylpyridine-3,5-dicarboxylate (DDC) as a porphyrinogenic agent. Fournal of Investigative Dermatology, 53, 400-413.

Mayer, T. C. and Fishbane, J. L. (1972). Mesoderm-ectoderm interaction in the production of the agouti pigmentation pattern in mice. Genetics, 71, 297-303.

Meara, R. H. (1958). Ehlers-Danlos syndrome and ? elastoma verruciforme perforans (Miescher). Case. Transactions of the St. Fohn's Hospital Dermatological Society, 40, 72.

Meyer, U. A., Strand, L. J., Doss, M., Rees, A. C., and Marver, H. S. (1972). Intermittent acute porphyria. Demonstration of a genetic defect in porphobilinogen metabolism. New England fourna of Medicine, 286, 1277-1282.

Milne, M. D. (1964). Disorders of amino-acid transport. British Medical fournal, 1, 327-336.

Milne, M. D., Asatoor, A., and Loughbridge, L. W. (1961). Hartnup disease and cystinuria. Lancet, 1, 51-52.

Minno, A. M. and Rogers, J. A. (1957). Ochronosis: report of a case. Annals of Internal Medicine, 46, 179-183.

Moore, M. R., Turnbull, A. L., Barnardo, D., Beattie, A. D., Magnus, I. A., and Goldberg, A. (1972). Hepatic $\delta$-aminolaevulinic acid synthetase activity in porphyria cutanea tarda. Lancet, 2, 97-100.

Moynahan, E. J. (1966). Hyalinosis cutis et mucosae (lipoid proteinosis). Demonstration of a new disorder of mucopolysaccharide metabolism. Proceedings of the Royal Society of Medicine, $\mathbf{5 9}$ 1125-1126.

Mudd, S. H., Finkelstein, J. D., Irreverre, F., and Laster, L. (1964). Homocystinuria: an enzymatic defect. Science, 143, 1443-1445.

Mullem, P. J. van and Ruiter, M. (1966). Elektronenmikroskopische Untersuchung der Haut bei Angiokeratoma corporis diffusum. Archiv fiur Klinische und Experimentelle Dermatologie, 226, 453-463.

Murphy, D. (1958). The dietetic treatment of phenylketonuria. Irish fournal of Medical Science, No. 391, 335-338.

O'Brien, J. S. and Sampson, E. L. (1966). Kinky hair disease. Biochemical studies. Fournal of Neuropathology and Experimental Neurology, 25, 523-530.

Parker, F. and Short, J. M. (1970). Xanthomatosis associated with hyperlipoproteinemia. Fournal of Investigative Dermatology, 55, 71-88.

Perdrup, A. and Poulsen, H. (1964). Hemochromatosis and vitiligo. Archives of Dermatology, 90, 34-37.

Perry, T. L. (1968). Homocystinuria: a challenging molecular disease. In Structural Chemistry and Molecular Biology, ed. by A. Rich, and N. R. Davidson, W. H. Freeman, San Francisco.

Pinnell, S. R., Krane, S. M., Kenzora, J. E., and Glimcher, M. J. (1972). A heritable disorder of connective tissue; hydroxylysinedeficient collagen disease. New England fournal of Medicine, 286, 1013-1020.
Pomeranz, M. M., Friedman, L. J., and Tunick, I. S. (1941). Roentgen findings in alcaptonuric ochronosis. Radiology, 37, 295303.

Porter, P. S. and Lobitz, W. C., Jr. (1970). Human hair: a genetic marker. British fournal of Dermatology, 83, 225-241.

Price, J., Vickers, C. F. H, and Brooker, B. K. (1968). A case of homocystinuria with noteworthy dermatological features. fournal of Mental Deficiency Research, 12, 111-118.

Rauschkolb, E. W., Freeman, R. G., and Farrell, G. (1968). Hair fragility. An important clue to amino-acidopathy in mental retardation. Cutis, 4, 1315-1318.

Reed, W. B., Ragsdale, W., Jr., Curtis, A. C., and Richards, H. J. (1968). Acanthosis nigricans in association with various genodermatoses: with emphasis on lipodystrophic diabetes and PraderWilli syndrome. Acta Dermatovenereologica, 48, 465-473.

Reed, W. B., Wuepper, K. D., Epstein, J. H., Redeker, A., Simonson, R. J., and McKusick, V. A. (1970). Erythropoietic protophyria: clinical and genetic study. Fournal of the American Medical Association, 214, 1060-1066.

Rothman, S. (1965). Physiology and Biochemistry of the Skin. 4th impression. University of Chicago Press, Chicago and London.

Sagebiel, R. W. and Parker, F. (1968). Cutaneous lesions of Fabry's disease: glycolipid lipidosis. Light and electron microscopic findings. Fournal of Investigative Dermatology, 50, 208-213.

Schetman, D. (1972). The Plummer-Vinson syndrome, a cutaneous manifestation of internal disease. Archives of Dermatology, $105,720-721$

Schmid, R. (1960). Cutaneous porphyria in Turkey. New England Fournal of Medicine, 263, 397-398.

Scott, F. P. and Findlay, G. H. (1960). Hyalinosis cutis et mucosae (lipoid proteinosis). South African Medical fournal, 34, 189-195.

Scriver, C. R. (1969). Inborn errors of amino-acid metabolism British Medical Bulletin, 25, 35-41.

Shapiro, M. P., Keen, P., Cohen, L., and Murray, J. F. (1953) Skin cancer in the South African Bantu. British Fournal of Cancer, 7, 45-57.

Smith, E. W., Malak, J. A., Goodman, R. M., and McKusick, V. A (1962). Reactive perforating elastosis: feature of certain genetic disorders. Bulletin of the fohns Hopkins Hospital, 111, 235-251.

Steinberg, D. (1972). Refsum's syndrome. In The Metabolic Basis of Inherited Disease, 3rd edition, ed. by Stanbury et al. McGraw-Hill, New York.

Steinberg, D., Mize, C. E., Herndon, J. H., Jr., Fales, H. M., Engel, W. K., and Vroom, F. Q. (1970). Phytanic acid in patients with Refsum's syndrome and response to dietary treatment. Archives of Internal Medicine, 125, 75-87.

Sweeley, C. C., Klionsky, B., Krivit, W., and Desnick, R. J. (1972). Fabry's disease. In The Metabolic Basis of Inherited Disease, 3rd edition, ed. by Stanbury et al, pp. 663-687. McGraw-Hill, New York.

Takahara, S. and Takahashi, H. (1972). An amine inducing alopecia in mice. Fournal of Biochemistry, 72, 195-197.

Virchow, R. (1866). Ein Fall von allgemeiner Ochronose der Knorpel und Knorpelähnlichen Theile. Archiv für Pathologische Anatomie und Physiologie und für klinische Medizin, 37, 212-219.

Waldorf, D. S., Levy, R. I., and Fredrickson, D. S. (1967). Cutaneous cholesterol ester deposition in Tangier disease. Archives of Dermatology, 95, 161-165.

Walshe, J. M. (1956). Penicillamine, a new oral therapy for Wilson's disease. American fournal of Medicine, 21, 487-495.

Wells, R. S., Higgs, J. M., Macdonald, A., Valdimarsson, H., and Holt, P. J. L. (1972). Familial chronic muco-cutaneous candidiasis. Fournal of Medical Genetics, 9, 302-310.

Wood, M. G., Urbach, F., and Beerman, H. (1956). Histochemical study of a case of ltpoid proteinosis. Fournal of Investigative Dermatology, 26, 263-274.

Young, T. E. (1957). Malignant melanoma in an albino: report of a case. Archives of Pathology, 64, 186-191.

Zannoni, V. G., Lomtevas, N., and Goldfinger, S. (1969). Oxidation of homogentisic acid to ochronotic pigment in connective tissue. Biochemica et Biophysica Acta, 177, 94-105. 